
\title{
$\begin{array}{ll}\text { Research Square } & \begin{array}{l}\text { Preprints are preliminary reports that have not undergone peer review. } \\ \text { They should not be considered conclusive, used to inform clinical practice, } \\ \text { or referenced by the media as validated information. }\end{array}\end{array}$
}

\section{Perspectives on Glucocorticoid treatment of COVID-19: a systematic review}

\section{Leonardo P. Cordeiro}

Faculdade de Medicina de Campos https://orcid.org/0000-0001-7885-870X

\section{Eduarda O.N.N. Linhares}

Faculdade de Medicina de Campos https://orcid.org/0000-0002-9269-557X

\section{Fernanda G.O. Nogueira}

Faculdade de Medicina de Campos https://orcid.org/0000-0002-2749-3955

Daniel JM Medeiros Lima ( $\nabla$ danieljmmlima@gmail.com )

Faculdade de Medicina de Campos https://orcid.org/0000-0003-4930-0533

\section{Systematic Review}

Keywords: Glucocorticoids, COVID-19, SARS-CoV-2, ARDS, Treatment

Posted Date: November 6th, 2020

DOI: https://doi.org/10.21203/rs.3.rs-103178/v1

License: @ (i) This work is licensed under a Creative Commons Attribution 4.0 International License. Read Full License

Version of Record: A version of this preprint was published at Pharmacological Reports on November 6th, 2020. See the published version at https://doi.org/10.1007/s43440-021-00225-3. 


\section{Abstract}

Coronavirus disease 2019 (COVID-19) is an on-going pandemic, this viral pneumonia can lead to a severe acute respiratory syndrome (SARS). Until the commercialization of a vaccine, pharmacological treatment still represents a great strategy to fight the disease. Glucocorticoids (GC) were widely used in the past coronavirus pandemics and it's been also used against the SARS-CoV-2. The aim of this study was to review the articles available about the use of GC in patients with COVID-19. In this systematic review randomized or nonrandomized clinical trials and retrospective or prospective controlled longitudinal studies were accepted. Participants could be of any clinical status, geographic location, age and sex. Studies in English, Portuguese and Spanish published since 2019 were included. The focuses of greatest interest were related to length of stay, changes in the radiological profile, viremia and mortality. The research was done electronically on the Pubmed database with the following terms: "corticosteroids", "glucocorticoids", "dexamethasone", "methylprednisolone", "COVID-19", "Sars- CoV-2", "ADRS". We identified 6,332 publications and at the end 14 were used since they met all inclusion criteria. All of them are retrospective observational studies. These studies included only patients infected with SARS-CoV-2 confirmed by RT-PCR, involving 2,713 participants. The results showed great heterogeneity in their designs and results, which precludes a reliable conclusion on the use of GCs in the treatment of COVID-19.

\section{Introduction}

Since December 2019, the world began to watch a new outbreak of pneumonia. Initially had an unknown cause and started in Wuhan, China. Subsequent investigations discovered that the agent was a new type of coronavirus ( $n$-cov) (1). The OMS catalogued this virus as 2019-nCOV, and in march 11th 2020 the disease was declared an epidemic.

2019-nCov is a ß-coronavirus that belongs to the family of coronavidae, being one of the seven who can affect humans. This virus has a simple positive sense RNA genome (+ssRNA). The lower respiratory system is the site primarily infected by the virus, and where it replicates.

(2)

Nowadays, it is known that acute respiratory distress syndrome (ARDS) is the main cause of death inherent in the coronavirus disease 2019 (COVID-19). The overexpression inflammatory cytokines in the cytoplasm of infected cells may indicate the immune mechanism responsible for this process. The term cytokine storm is caused because it characterizes the serum increase of interleukin 1B (IL-1B), Interferon gamma (IFN-y), monocyte chemoattracting protein 1 (MCP-1), Interleucine-6 (IL-6). The IL-6 has been used as a marker of the disease severity since its rates suggest being higher together with granulocyte colony stimulating factor (G-CSF) and tumor necrosis factor alpha (TNF-a) in critically ill patients in intensive care units (ICU). (3)

Several interventions have been tested through more than 1.500 types of randomized clinical trials, such as the use of antimalarials, plasmaphereses, antivirals, anticoagulants, immunobiologics and glucocorticoids (GC) (4-8). This kind of treatment has the aim to prevent the progress of de disease and improve the prognosis of patients.

GCs were widely used as immunomodulators during 2002 in the epidemic phase of the severe acute respiratory syndrome (SARS), because its early use led to an improvement in pulmonary oxygenation, a reduction in fever, a decrease in hospital stay and consequent mortality. (3) This evidence led to the study of the use of this class of drugs in the epidemic of SARS-CoV-2.

Patients who have a high inflammatory response and a high risk of developing ARDS or in the early stage of the cytokine storm, the use of these steroids may be useful (3,9-11). 
The use of GC must be judicious despite its benefits. Its administration in large doses may delay the clearance of the respiratory tract virus and increase the risk of secondary infections in addition to inducing high complication rates. (10)

The aim of this study was to review the articles available about the use of GC in patients with COVID-19 and to provide a safer analysis of the effectiveness and recommendations for its use.

\section{Materials And Methods}

A systematic review was carried out on the use of GC in cases of COVID-19, for which the preferred reporting items were used for systematic reviews and meta analyses (PRISMA). (12) The New Casttle-Otawa scale was used as protocol for the analysis and methodology of longitudinal studies. For the randomized clinical trials, the Jadad scale was chosen.

Were accepted randomized or nonrandomized clinical trials and retrospective or prospective controlled longitudinal studies using GC as an intervention for the treatment of patients with COVID-19. The participants could be of any clinical status, geographic location, age and sex. Studies in English, Portuguese and Spanish published since 2019 were included and only articles already published were evaluated. Exclusion criteria included case-control studies, case reports and reviews. Studies in different languages than those cited as inclusion factors and not yet published have not been included as well.

The focuses of greatest interest were related to length of stay, changes in the radiological profile, viremia, serum cytokine rate and clinical status; in addition to mortality. The choices took into account the emergency of this review due to the current pandemic and the commitment to presenting safe data to the reader.

The research was done electronically and used the Pubmed database, where a daily alert was created regarding the search for the permutation of the following terms: "corticosteroids", "glucocorticoids", "dexamethasone", "methylprednisolone", "COVID-19", "Sars-CoV-2", "ADRS". The result of the research can be consulted in figure 1. The date of the first survey was 31/05/2020 and the last one was made on $21 / 07 / 2020$.

The primary analysis of the articles found was done independently by two authors ( $L$ and $E$ ) by reading the titles and abstracts. Those studies that met the inclusion criteria were read in full by the authors ( $L$ and $E$ ) and those that did not present any new evidence to justify their withdrawal were used in this review. Any doubts about the inclusion of these articles were discussed between the authors $(L$ and $E)$ and a third author (D) in search of a consensus.

\section{Results}

The systematic review identified 6,332 publications and at the end 14 were used since they met all inclusion criteria. All of them are retrospective observational studies. 12 were performed in China (13-26), 1 in Spain (25) and 1 in the United States (26). These studies included only patients infected with SARS-CoV-2 confirmed by RT-PCR, involving 2,713 participants. There was variation in the severity of the disease presented by the participants in the different studies as well as in the protocol, record and type of GC used. The score obtained on the NOS scale for the analysis of possible bias in observational studies was 4 to 8 , short follow-up time was the main limiting factor presented.

The evaluated outcomes showed considerable heterogeneity, such as changes in clinical, radiological or laboratory status, duration of hospital stay, time for viral clearance and mortality. The interpretation of the results obtained in some studies was limited by the absence or insufficiency of statistical data. Due to the great variability and limitations of the studies, the results obtained regarding the consequences of using GCs were also complex and sometimes conflicting, as further discussed. 


\section{Discussion}

In the epidemics of SARS and Middle East Respiratory Syndrome (MERS) the use of GC has been widely discussed, however, the safety and efficacy of this pharmacological class is still controversial. Evidence found in systematic reviews suggests that the administration of GC in patients with SARS is associated with increased plasma viral load and slower viral clearance, contributing to immunosuppression states (27-30). In patients with MERS, although no association was found between the use of GCs and increased mortality, there was a delay in the clearance of MERS-CoV RNA $(27,29,30)$. Studies still indicate that in addition to the use of corticosteroids, it did not have an impact on reducing the number of deaths, the use led to prolonged hospital stay, ICU admission rate and / or the use of mechanical ventilation, as well as the appearance of important adverse effects (30).

A cohort found that all patients had a significant increase in the viral load of SARS-CoV in the body, however, there was a considerable reduction in IL-6, IL-8 and IL-10 in patients with 7-10 days of treatment with corticosteroids, coinciding with the improvement of the clinical and radiological situation (31). Another cohort identified a higher mortality rate in patients treated with corticosteroids with no lung damage, indicating that the early use of this pharmacological class would significantly increase the viral load (32).

In a clinical trial in which two groups of patients with MERS were compared, corticosteroid therapy was applied in one and not in another, it was observed that in the corticoid group, mechanical ventilation, administration of nitric oxide, the use of neuromuscular blockers, vasopressors, blood transfusion and renal replacement therapy, in addition to having delayed viral clearance (33). Loutfy et al observed that among 13 patients diagnosed with SARS who were treated with single corticosteroid therapy, 5 were transferred to the ICU, 3 were intubated and underwent mechanical ventilation and one patient died (34). Lee et al observed the early administration ( $<7$ days) of hydrocortisone in 9 patients with SARS and concluded that the expression of SARS-CoV RNA was significantly higher in the hydrocortisone group than in the placebo group (35).

Our analysis of studies using GC in the treatment of COVID-19 patients must be interpreted with great caution. Due to the emergency of immediate responses that can guide medical conduct, we collected as much data as possible on this subject, which leads to a grouping of studies with significant differences regarding the status of the selected patients, GC dosage, period of use, outcome and analyzes used in relation to the data obtained. Another important fact is that all studies obtained are observational and retrospective, preventing the careful choice of who will or will not receive the medication. As GC tend to be used for more severe patients, the interpretation of such outcomes may be subject to selection bias. Thus, it is impossible to ensure that the criteria for administration of GC were pre-established or based on a worsening of the clinical status, admission to the ICU, changes in laboratory or radiological data.

By stratifying the interpretation of results according to the type of outcome, we can draw more secure conclusions associated with a careful individual analysis of the articles. Eight articles evaluated mortality as an outcome (13,16,18,19,22,24-26), of these, two did not present statistical analysis and, therefore, were not included in this discussion $(18,24)$. Two cohorts, in spite of expressing the $p$ value attached to the table, did not show significance between the variables, thereby they were not inserted as well $(13,19)$. Among the remaining four, two included patients in any disease state and found results against the use of GC $(16,26)$. Cruz et al included only critically ill patients and used GC administration as exposure, bringing a stronger conclusion, in addition to having the highest note in the NOS score among those included (25). In this study, mortality was lower in the group that used CG. Wu et al observed the development of ARDS and mortality in the hospitalized patients and concluded that the use of Methylprednisolone was greater in the group that developed ARDS and in this group the use was larger among those who survived, but this latter result did not obtain statistical significance (22).

Four articles analyzed the time to viral clearance $(14,15,17,23)$. Of these, only one obtained a significant result $(23)$. The cohort included patients in any condition and concluded that the use of GC was greater in the group that took longer to certify viral clearance. Finally, two articles analyzed clinical changes $(20,21)$. Wang et al included only critically ill patients and observed results in favor of the use of Methylprednisolone. Shang et al included patients in any condition and used three different GC and observed, among the survivors, longer hospital stay in the group that received GC, but also a significant recovery in the lymphocyte count among those who received the medication and survived. 
Recently, the multinational guideline Surviving Sepsis for COVID-19 recommended the use of steroids in patients with severe conditions and on mechanical ventilation, the purpose of which is to reduce the destructive risk, based on immunological evidence (36). The most discerning evidence to date, the RECOVERY study, brings in primary analyzes a reduction in mortality and length of hospital stay with the use of Dexamethasone (37).

The use of GC has shown a direct relationship with the development of hypercortisolism, especially in patients with individual hypersensitivity or hypoadrenalism after discontinuation of the drug. In addition, it is known that most patients are treated with antiretroviral drugs, such as Ritonavir, which acts as an inhibitor of cytochrome P4503A enzymes. By increasing the concentrations of a drug metabolized by the same route, such as GCs, this enzyme inhibitor can promote a hypercortisolemic condition $(38,39)$.

Chronic use of high-dose GC followed by abrupt interruption can trigger tertiary adrenal insufficiency. Thus, the therapeutic use of these drugs must be done with care (40). Finally, it is important to remember the hyperglycemic potential of GC, which can be crucial in the care of diabetic patients with COVID-19 The prospective RECOVERY study, however, found no evidence that GCs induce hyperglycemia more than standard therapy (37).

\section{Limitations}

This systematic review has important limitations. Due to the emergency of the study, we selected articles with notable differences in terms of their base populations, clinical status of the participants, analyzed outcome and corticotherapy used. The lack of more careful studies such as prospective cohorts or randomized controlled trials also limits the data gathered in our study.

\section{Conclusion}

In view of the studies that were analyzed in this review, we can come up with some observations that can assist us in the therapeutic conduct with GC in patients with COVID-19. Understanding the pathophysiological basis of COVID-19 is crucial for good clinical reasoning and the consequent prescription of GCs, since studies have shown that more severe patients on ventilatory support seem to have a greater benefit from GC therapy. The main observation is the reduction of the characteristic inflammatory markers in the most severe phase of the disease, which can result in pulmonary complications leading to a disorganization of the alveolar microvasculature. However, the studies are not strong enough to lead us to a reliable conclusion, but we emphasize that its use must be carried out with discretion and caution for a better prognosis.

\section{Declarations}

\section{Funding}

None

\section{Conflict of interest}

None

\section{Author contributions}

Conceived the idea: L, E, D. Wrote the manuscript: L, E, F, D. Reviewed critically for content: L, E. All authors approved the final manuscript and submission. 


\section{References}

1. Chen Y, Liu Q, Guo D. Emerging coronaviruses: Genome structure, replication, and pathogenesis. J Med Virol. 2020;92(4):418-23.

2. Schoeman D, Fielding BC. Coronavirus envelope protein: Current knowledge. Virol J. 2019;16(1):1-22.

3. Ye Q, Wang B, Mao Since January 2020 Elsevier has created a COVID- 19 resource centre with free information in English and Mandarin on the novel coronavirus COVID-19. The COVID-19 resource centre is hosted on Elsevier Connect, the company 's public news and information . 2020;(January).

4. Search of: glucocorticoids | Covid-19 - List Results - ClinicalTrials.gov [Internet]. [cited 2020 Jun 2]. Available from: https://clinicaltrials.gov/ct2/results?cond=Covid- 19\&term=glucocorticoids\&cntry=\&state=\&city=\&dist=\&Search=Search

5. Search of: remdesivir | Covid-19 - List Results - gov [Internet]. [cited 2020 Jun 2]. Available from: https://clinicaltrials.gov/ct2/results? cond=Covid- $19 \&$ term $=$ remdesivir $\&$ cntry $=\&$ state $=\&$ city $=\&$ dist $=\&$ Search $=$ Search

6. Search of: plasmaphereses | Covid-19 - List Results - ClinicalTrials.gov [Internet]. [cited 2020 Jun 2]. Available from: https://clinicaltrials.gov/ct2/results?term=plasmaphereses\&cond=Covid-19

7. Search of: anticoagulant | Covid-19 - List Results - ClinicalTrials.gov [Internet]. [cited 2020 Jun 2]. Available from: https://clinicaltrials.gov/ct2/results?cond=Covid- 19\&term=anticoagulant\&cntry=\&state=\&city=\&dist=

8. Search of: chloroquine | Covid-19 - List Results - ClinicalTrials.gov [Internet]. [cited 2020 Jun 2]. Available from: https://clinicaltrials.gov/ct2/results?term=chloroquine\&cond=Covid-19

9. Vandewalle J, Luypaert A, De Bosscher K, Libert C. Therapeutic Mechanisms of Glucocorticoids. Trends Endocrinol Metab [Internet]. 2018;29(1):42-54. Available from: http://dx.doi.org/10.1016/j.tem.2017.10.010

10. Sanders JM, Monogue ML, Jodlowski TZ, Cutrell JB. Pharmacologic Treatments for Coronavirus Disease 2019 (COVID-19): A Review. JAMA - J Am Med Assoc. 2020;2019.

11. Brunton LL, \& G, Gilman. As Bases Farmacológicas da Terapêutica. 12th ed. Rio de Janeiro: McGraw-Hilll;

12. Itens P, Revis R, Uma P. Principais itens para relatar Revisões sistemáticas e Meta-análises: A recomendação PRISMA. Epidemiol e Serviços Saúde. 2015;24(2):335-42.

13. Cao J, Tu W, Cheng W, Yu L, Liu Y, Hu X, et al. Clinical Features and Short-term Outcomes of 102 Patients with Corona Virus Disease 2019 in Wuhan, China 1 . Department of Cardiology , Zhongnan Hospital , Wuhan University , Wuhan , China 2. Institute of Radiation Medicine, China Academy of Medical Sc. 2019;(238).

14. Fang X, Mei Q, Yang T, Li L, Wang Y, Tong F, et Low-dose corticosteroid therapy does not delay viral clearance in patients with COVID-19. $J$ Infect [Internet]. 2020; Available from: https://doi.org/10.1016/j.jinf.2020.03.039

15. Zha L, Li S, Pan L, Tefsen B, Li Y, French N, et Corticosteroid treatment of patients with coronavirus disease 2019 (COVID-19). Med J Aust. 2020;212(9):416-20.

16. Zhou F, Yu T, Du R, Fan G, Liu Y, Liu Z, et al. Clinical course and risk factors for mortality of adult inpatients with COVID-19 in Wuhan, China: a retrospective cohort study. Lancet [Internet]. 2020;395(10229):1054-62. Available from: http://dx.doi.org/10.1016/S01406736(20)30566-3

17. Gong Y, Guan L, Jin Z, Chen S, Xiang G, Gao Effects of methylprednisolone use on viral genomic nucleic acid negative conversion and CT imaging lesion absorption in COVID-19 patients under 50 years old. J Med Virol. 2020;0-3.

18. Guan W, Ni Z, Hu Y, Liang W, Ou C, He J, et al. Clinical characteristics of coronavirus disease 2019 in China. N Engl J Med. 2020;382(18):1708-20.

19. Li J, Xu G, Yu H, Peng X, Luo Y, Cao C. Clinical characteristics and outcomes of 74 patients with severe or critical COVID-19. Am J Med Sci. 2020;1-7. 
20. Shang J, Du R, Lu Q, Wu J, Xu S, Ke Z, et The Treatment and Outcomes of Patients with COVID-19 in Hubei, China: A Multi-Centered, Retrospective, Observational Study. SSRN Electron J. 2020;

21. Wang Y, Jiang W, He Q, Wang C, Wang B, Zhou P, et al. Early, low-dose and short-term application of corticosteroid treatment in patients with severe COVID-19 pneumonia: single-center experience from Wuhan, China. medRxiv [Internet]. 2020;2020.03.06.20032342.

Available from: http://medrxiv.org/content/early/2020/03/12/2020.03.06.20032342.abstrac $t$

22. Wu C, Chen X, Cai Y, Xia J, Zhou X, Xu S, et al. Risk Factors Associated with Acute Respiratory Distress Syndrome and Death in Patients with Coronavirus Disease 2019 Pneumonia in Wuhan, JAMA Intern Med. 2020;1-10.

23. Xu K, Chen Y, Yuan J et al. Factors asssociated with prolonged viral RNA shedding in patients with coronavirus disease 2019 (COVID19). Clin Infect Dis. 2020;71(15):799-806.

24. Yang X, Yu Y, Xu J, Shu H, Xia J, Liu H, et Clinical course and outcomes of critically ill patients with SARS-CoV-2 pneumonia in Wuhan, China: a single-centered, retrospective, observational study. Lancet Respir Med [Internet]. 2020;8(5):475-81. Available from: http://dx.doi.org/10.1016/S2213-2600(20)30079-5

25. Fernández Cruz A, Ruiz-Antorán B, Muñoz Gómez A, Sancho López A, Mills Sánchez P, Centeno Soto GA, et al. Impact of Glucocorticoid Treatment in Sars-Cov-2 Infection Mortality: a Retrospective Controlled Cohort Study. Antimicrob Agents Chemother. 2020;(June).

26. Salacup G, Do DJIII, Do RB, Pelayo J, Albano J. Characteristics and Clinical Outcomes of COVID-19 Patients in an Underserved-Inner City Population: A Single Tertiary Center Cohort. :0-2.

27. Arabi YM, Fowler R, Hayden FG. Critical care management of adults with community-acquired severe respiratory viral infection. Intensive Care Med [Internet]. 2020;46(2):315-28. Available from: https://doi.org/10.1007/s00134-020-05943-5

28. Rabaan AA, Alahmed SH, Bazzi AM, Alhani HM. A review of candidate therapies for middle east respiratory syndrome from a molecular perspective. J Med Microbiol. 2017;66(9):1261-74.

29. Mo Y, Fisher D. A review of treatment modalities for Middle East Respiratory Syndrome. J Antimicrob Chemother. 2016;71(12):334050.

30. Li H, Chen C, Hu F, Wang J, Zhao Q, Gale RP, et al. Impact of corticosteroid therapy on outcomes of persons with SARS-CoV-2, SARSCoV, or MERS-CoV infection: a systematic review and meta-analysis. Leukemia [Internet]. 2020;34(6):1503-11. Available from: http://dx.doi.org/10.1038/s41375-020-0848-3

31. Ng PC, Lam CWK, Li AM, Wong CK, Cheng FWT, Leung TF, et al. Inflammatory Cytokine Profile in Children With Severe Acute Respiratory Syndrome. Pediatrics. 2004;113(1).

32. Lau ACW, So LKY, Miu FPL, Yung RWH, Poon E, Cheung TMT, et al. Outcome of coronavirus-associated severe acute respiratory syndrome using a standard treatment protocol. Respirology. 2004;9(2):173-83.

33. Arabi YM, Mandourah Y, Al-Hameed F, Sindi AA, Almekhlafi GA, Hussein MA, et al. Corticosteroid therapy for critically ill patients with middle east respiratory syndrome. Am J Respir Crit Care Med. 2018;197(6):757-67.

34. Loutfy MR, Blatt LM, Siminovitch KA, Ward S, Wolff B, Lho H, et al. Interferon Alfacon-1 Plus Corticosteroids in Severe Acute Respiratory Syndrome: A Preliminary Study. J Am Med Assoc. 2003;290(24):3222-8.

35. Lee N, Allen Chan KC, Hui DS, Ng EKO, Wu A, Chiu RWK, et Effects of early corticosteroid treatment on plasma SARS-associated Coronavirus RNA concentrations in adult patients. J Clin Virol. 2004;31(4):304-9.

36. Alhazzani W, Møller MH, Arabi YM, Loeb M, Gong MN, Fan E, et al. Surviving Sepsis Campaign: guidelines on the management of critically ill adults with Coronavirus Disease 2019 (COVID-19) [Internet]. Vol. 46, Intensive Care Medicine. Springer Berlin Heidelberg; 2020. 854-887 p. Available from: https://doi.org/10.1007/s00134-020-06022-5

37. Horby P, Lim WS, Emberson J, Mafham M, Bell J, Landary MJ, et Effect of Dexamethasone in Hospitalized Patients with COVID-19 Preliminary Report. MedRvix. 2020;http://doi.org/10.5281/zenodo.3928540. 
38. Berton AM, Prencipe N, Giordano R, Ghigo E, Grottoli Systemic steroids in patients with COVID-19: pros and contras, an endocrinological point of view. J Endocrinol Invest [Internet]. 2020;(0123456789):19-21. Available from: https://doi.org/10.1007/s40618-020-01325-2

39. Scaroni C, Armigliato M, Cannavò S. COVID-19 outbreak and steroids administration: are patients treated for Sars-Cov-2 at risk of adrenal insufficiency? J Endocrinol Invest [Internet]. 2020;43(7):1035-6. Available from: https://doi.org/10.1007/s40618-020-01253-1

40. Almeida MQ, Mendonca BB. Adrenal Insufficiency and Glucocorticoid Use During the COVID-19 Pandemic. Clinics (Sao Paulo). 2020;75:e2022.

\section{Tables}

Table 1 


\begin{tabular}{|c|c|c|c|c|c|c|c|}
\hline $\begin{array}{l}\text { Study } \\
\text { ID }\end{array}$ & Design & Country & Site & $\begin{array}{l}\text { NOS/Jaded } \\
\text { score }\end{array}$ & Age (I vs C) & $\begin{array}{l}\text { N } \\
\text { (used } \\
\text { GC vs } \\
\text { didn't } \\
\text { use } \\
\text { GC) }\end{array}$ & Gender Male/Total (I vs C) \\
\hline Guan & Cohort & China & $\begin{array}{l}\text { Multi- } \\
\text { center }\end{array}$ & 5 & $\begin{array}{l}\text { Severe: } 52.0 \\
\text { (40.0-65.0) } \\
\text { Nonsevere: } \\
45.0(34.0-57.0)\end{array}$ & $\begin{array}{l}204 \\
895\end{array}$ & Severe: $100 / 173$ Nonsevere: $537 / 923$ \\
\hline Yang & Cohort & China & $\begin{array}{l}\text { Single } \\
\text { center }\end{array}$ & 6 & $\begin{array}{l}\text { Survivors: } 51 \cdot 9 \\
(12 \cdot 9) \\
\text { Nonsurvivors: } \\
64 \cdot 6(11 \cdot 2)\end{array}$ & $30 ; 22$ & Survivors: $14 / 20$ Nonsurvivors: $21 / 32$ \\
\hline Zhou & Cohort & China & $\begin{array}{l}\text { Two } \\
\text { centers }\end{array}$ & 6 & $\begin{array}{l}\text { Survivors: } 52 \cdot 0 \\
(45 \cdot 0-58 \cdot 0) \\
\text { Nonsurvivors: } \\
69 \cdot 0(63 \cdot 0-76 \cdot 0)\end{array}$ & $\begin{array}{l}57 \\
134\end{array}$ & Survivors: $81 / 137$ Nonsurvivors: $38 / 54$ \\
\hline Cao & Cohort & China & $\begin{array}{l}\text { Single } \\
\text { center }\end{array}$ & 6 & $\begin{array}{l}\text { Survivors: } 53 \text { (47- } \\
66) \text { Nonsurvivors: } \\
72 \\
(63-81)\end{array}$ & $51 ; 51$ & Survivors: 40/85 Nonsurvivors: $13 / 17$ \\
\hline Salacup & Cohort & USA & $\begin{array}{l}\text { Single } \\
\text { center }\end{array}$ & 6 & $\begin{array}{l}\text { Survivors: } \\
64.08 \pm 15.07 \\
\text { Nonsurvivors: } \\
73.15 \pm 11.01\end{array}$ & $\begin{array}{l}55 \\
187\end{array}$ & Survivors: $96 / 190$ Nonsurvivors: $27 / 52$ \\
\hline Li & Cohort & China & $\begin{array}{l}\text { Single } \\
\text { center }\end{array}$ & 6 & $\begin{array}{l}\text { Survivors: } 62 \text { (53- } \\
70) \text { Nonsurvivors: } \\
71 \\
(69-77)\end{array}$ & $70 ; 4$ & Survivors: $33 / 60$ Nonsurvivors: $11 / 14$ \\
\hline Zha & Cohort & China & $\begin{array}{l}\text { Two } \\
\text { centers }\end{array}$ & 8 & $\begin{array}{l}\text { Corticosteroid: } 53 \\
(36-57) \\
\text { Noncorticosteroid: } \\
37(27-52)\end{array}$ & $11 ; 20$ & $\begin{array}{l}\text { Corticosteroid: } 8 / 11 \text { Noncorticosteroid: } \\
12 / 20\end{array}$ \\
\hline Wang & Cohort & China & $\begin{array}{l}\text { Single } \\
\text { center }\end{array}$ & 8 & $\begin{array}{l}\text { Corticosteroid: } \\
54(48,63) \\
\text { Noncorticosteroid: } \\
53(48,63)\end{array}$ & $26 ; 20$ & $\begin{array}{l}\text { Corticosteroid: } 16 / 26 \text { Noncorticosteroid: } \\
10 / 20\end{array}$ \\
\hline Gong & Cohort & China & $\begin{array}{l}\text { Single } \\
\text { center }\end{array}$ & 4 & $\begin{array}{l}\text { Corticosteroid: } \\
38.22 \pm 8.95 \\
\text { Noncorticosteroid: } \\
33.75 \pm 7.80\end{array}$ & $18 ; 16$ & $\begin{array}{l}\text { Corticosteroid: } 11 / 18 \text { Noncorticosteroid: } \\
11 / 16\end{array}$ \\
\hline Cruz & Cohort & Spain & $\begin{array}{l}\text { Single } \\
\text { center }\end{array}$ & 7 & $\begin{array}{l}\text { Corticosteroid: } \\
65.4(12.9) \\
\text { Noncorticosteroid: } \\
68.1(15.7)\end{array}$ & $\begin{array}{l}396 \\
67\end{array}$ & $\begin{array}{l}\text { Corticosteroid: } 276 / 396 \text { Noncorticosteroid: } \\
41 / 67\end{array}$ \\
\hline Fang & Cohort & China & $\begin{array}{l}\text { Single } \\
\text { center }\end{array}$ & 7 & $\begin{array}{l}\text { Corticosteroid: } \\
\text { General group - } \\
40.2 \pm 12.6 . \text { Severe } \\
\text { Group - } 60.6 \pm 13.6 \\
\text { Noncorticosteroid: } \\
\text { General group - } \\
39.9 \pm 15.5 . \text { Severe } \\
\text { group - } 54.3 \pm 15.4\end{array}$ & $25 ; 53$ & $\begin{array}{l}\text { Corticosteroid: General group - 5/9. } \\
\text { Severe Group - } 12 / 16 \text { Noncorticosteroid: } \\
\text { General group - 22/46. Severe group - } 5 / 7\end{array}$ \\
\hline Wu & Cohort & China & Single & 6 & $\begin{array}{l}\text { Without ARDS: } \\
\text { Page } 9 / 12\end{array}$ & $62 ;$ & Without ARDS: \\
\hline
\end{tabular}




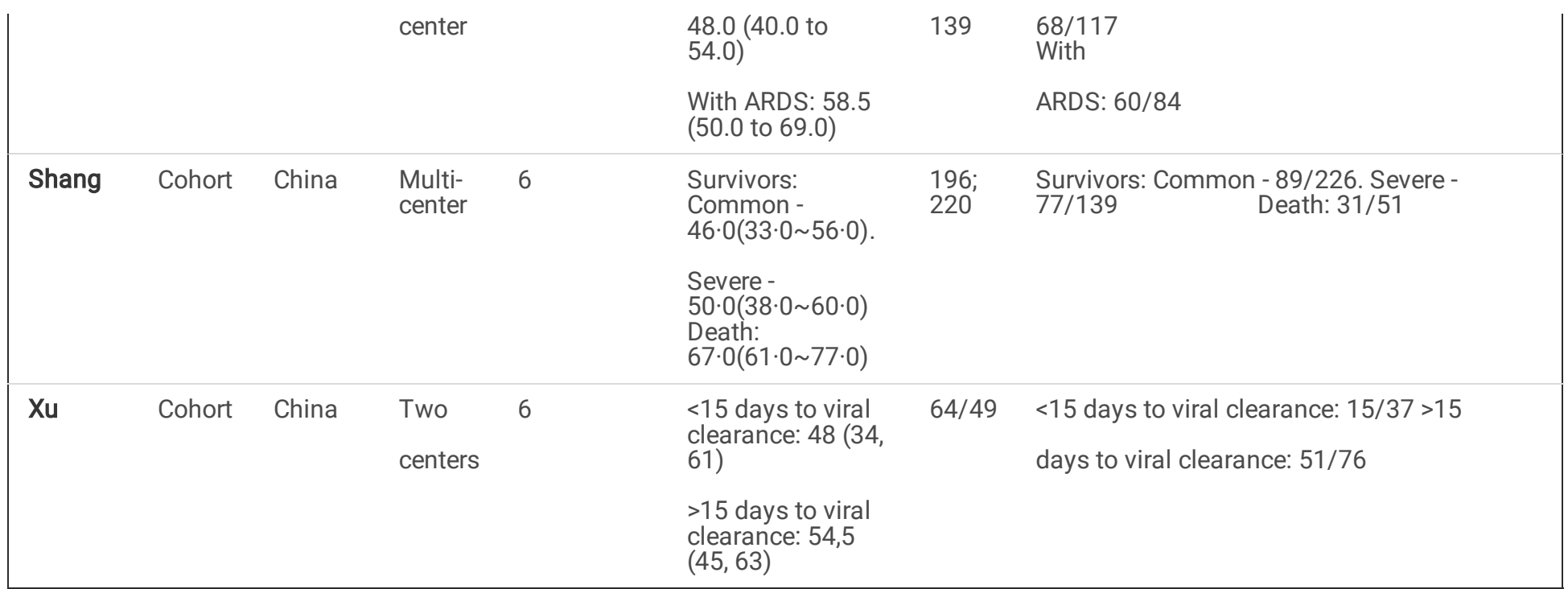

Table 2

\begin{tabular}{|c|c|c|c|c|}
\hline $\begin{array}{l}\text { Study } \\
\text { ID }\end{array}$ & $\begin{array}{l}\text { Severity } \\
\text { of disease }\end{array}$ & Type, dose and duration & Outcome & Result \\
\hline Guan & $\begin{array}{l}\text { Severe/ } \\
\text { Nonsevere }\end{array}$ & Systemic glucocorticoids & $\begin{array}{l}\text { Admission to an } \\
\text { (ICU), the use of } \\
\text { mechanical } \\
\text { ventilation, or } \\
\text { death }\end{array}$ & Higher percentage among those without outcome \\
\hline Yang & $\begin{array}{l}\text { Critically } \\
\text { ill }\end{array}$ & Glucocorticoids & $\begin{array}{l}\text { 28-day mortality } \\
\text { after ICU } \\
\text { admission }\end{array}$ & Higher percentage among those without outcome \\
\hline Zhou & All & Corticosteroids & Mortality & $\begin{array}{l}\text { Higher percentage among those with outcome with } \\
\text { statistical difference }\end{array}$ \\
\hline Cao & All & $\begin{array}{l}\text { Methylprednisolone Sodium } \\
\text { Succ }\end{array}$ & Mortality & $\begin{array}{l}\text { Higher percentage among those with outcome but } \\
\text { no statistical difference }\end{array}$ \\
\hline Salacup & All & Steroids & Mortality & $\begin{array}{l}\text { Higher percentage among those with outcome with } \\
\text { statistical difference }\end{array}$ \\
\hline Li & $\begin{array}{l}\text { Severe } \\
\text { and } \\
\text { critical }\end{array}$ & Corticosteroids & Mortality & $\begin{array}{l}\text { Higher percentage among those without outcome } \\
\text { but no statistical difference }\end{array}$ \\
\hline Zha & Mild & $\begin{array}{l}40 \text { mg Methylprednisolone } \\
\text { once or twice per day within } 24 \\
\text { hours of admission for a } \\
\text { median } 5 \text { days }\end{array}$ & $\begin{array}{l}\text { Time to virus } \\
\text { clearance }\end{array}$ & $\begin{array}{l}\text { No statistically significant differences in virologic or } \\
\text { clinical outcomes between patients who received } \\
\text { and those who did not receive corticosteroid }\end{array}$ \\
\hline Wang & Severe & $\begin{array}{l}\text { Methylprednisolone treatment } \\
\text { with the dosage of } 12 \mathrm{mg} / \mathrm{kg} / \mathrm{d} \\
\text { for } 5-7 \text { days }\end{array}$ & $\begin{array}{l}\text { Clinical, laboratory } \\
\text { and radiological } \\
\text { improvement }\end{array}$ & $\begin{array}{l}\text { Better statistically significant improvement among } \\
\text { those who received methylprednisolone in duration } \\
\text { of fever, Sp02 and absorption degree of the focus in } \\
\text { chest CT }\end{array}$ \\
\hline
\end{tabular}




\begin{tabular}{|c|c|c|c|c|}
\hline Gong & All & $\begin{array}{l}\text { Methylprednisolone as } 1-2 \mathrm{mg} / \mathrm{kg} / \mathrm{d} \text { in } \\
\text { the initial dose and gradually halved } \\
\text { every } 3 \text { days, total treating course range } \\
\text { from } 5 \text { to } 10 \text { days }\end{array}$ & $\begin{array}{l}\text { Viral genomic } \\
\text { nucleic } \\
\text { acid negative } \\
\text { conversion } \\
\text { and CT } \\
\text { imaging lesion } \\
\text { absorption }\end{array}$ & $\begin{array}{l}\text { No statistical difference in the CT } \\
\text { imaging lesion } \\
\text { absorption in both } 2 \text { groups but shorter } \\
\text { time needed to viral genomic nucleic } \\
\text { acid negative conversion in the } \\
\text { methylprednisolone group }\end{array}$ \\
\hline Cruz & $\begin{array}{l}\text { COVID-19 patients } \\
\text { complicated with } \\
\text { ARDS and/or an } \\
\text { hyperinflammatory } \\
\text { syndrome }\end{array}$ & $\begin{array}{l}1 \mathrm{mg} / \mathrm{kg} / \text { day Methylprednisolone or } \\
\text { equivalent, and steroid pulse }\end{array}$ & $\begin{array}{l}\text { In-hospital } \\
\text { mortality }\end{array}$ & $\begin{array}{l}\text { In-hospital mortality was lower in } \\
\text { patients treated with steroids than in } \\
\text { controls }\end{array}$ \\
\hline Fang & General and severe & $\begin{array}{l}\text { Oral methylprednisolone, } 237.5 \mathrm{mg} / \mathrm{day} \\
\text { for a median duration of } 7 \text { days in the } \\
\text { general group. Intravenous } \\
\text { methylprednisolone, } 250.0 \mathrm{mg} / \mathrm{day} \text { for a } \\
\text { median duration of } 4.5 \text { days in the } \\
\text { severe group }\end{array}$ & $\begin{array}{l}\text { Time to virus } \\
\text { clearance }\end{array}$ & $\begin{array}{l}\text { No significant difference identified in } \\
\text { both patients in the general group and } \\
\text { patients in the severe group }\end{array}$ \\
\hline Wu & All & Methylprednisolone & $\begin{array}{l}\text { Development } \\
\text { of ARDS and } \\
\text { death among } \\
\text { those with } \\
\text { ARDS }\end{array}$ & $\begin{array}{l}\text { Patients who developed ARDS were } \\
\text { more likely to be treated with } \\
\text { methylprednisolone and the } \\
\text { administration of methylprednisolone } \\
\text { appears to have reduced the risk of } \\
\text { death in patients with ARDS }\end{array}$ \\
\hline Shang & All & $\begin{array}{l}\text { methylprednisolone, prednisone acetate, } \\
\text { and dexamethasone }\end{array}$ & $\begin{array}{l}\text { Hospitalization } \\
\text { time and } \\
\text { clinical and } \\
\text { laboratory } \\
\text { changing }\end{array}$ & $\begin{array}{l}\text { Survivors who received corticosteroid } \\
\text { therapy had a longer duration of } \\
\text { hospitalization and there was a } \\
\text { significant recovery of lymphocyte } \\
\text { counts after corticosteroids therapy for } \\
\text { the survivors but not the deaths. }\end{array}$ \\
\hline $\mathrm{Xu}$ & All & Corticosteroids & $\begin{array}{l}\text { Time to virus } \\
\text { clearance }\end{array}$ & $\begin{array}{l}\text { Higher percentage among the }>15 \text { days } \\
\text { to virus clearence group with statistical } \\
\text { difference }\end{array}$ \\
\hline
\end{tabular}

\section{Figures}




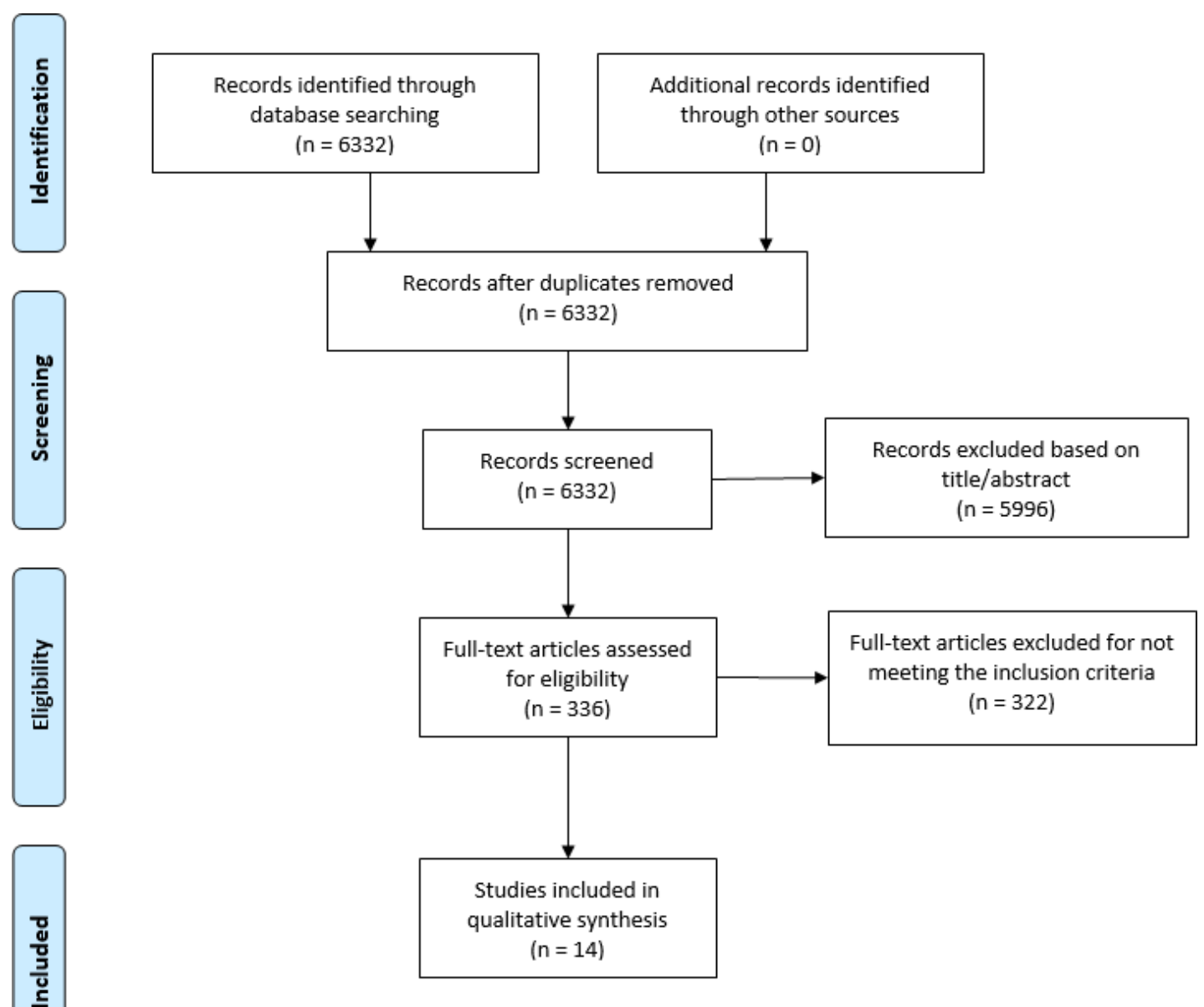

\section{Figure 1}

PRISMA Flow Diagram

\section{Supplementary Files}

This is a list of supplementary files associated with this preprint. Click to download.

- Results.xIsm 